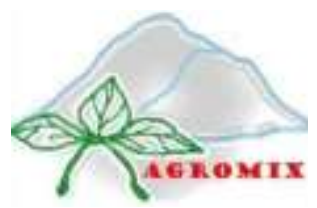

\title{
AGROMIX
}

Jurnal IImiah Fakultas Pertanian, Universitas Yudharta Pasuruan pISSN (Print): 2085-241X; elSSN (Online): 2599-3003

Website: https://jurnal.yudharta.ac.id/v2/index.php/agromix

\section{Pengaruh pelatihan pengolahan hasil ubi kayu dan ubi jalar di Balai Besar Pelatihan Pertanian Ketindan terhadap peningkatan kinerja penyuluh pertanian}

\author{
The effect of training on the processing of cassava and sweet potato at Indonesian Centre Agricultural Training \\ Ketindan for improving the performance of the agricultural extension
}

\author{
Murdani $^{\mathbf{1}^{*}}$, Dewi Melani ${ }^{1}$ \\ ${ }^{1}$ Balai Besar Pelatihan Pertanian Ketindan, Ketindan No.1 Lawang, Malang, Jawa Timur \\ *Email korespondensi: widyamurdani@yahoo.co.id
}

\section{Article History \\ Received : July 8, 2021 \\ Accepted : September 15, 2021 \\ Published : September 28, 2021 \\ Keyword \\ Training; performance; agricultural extension; sweet potato; cassava}

\section{ABSTRACT}

This study aims to determine the effect of training on processing cassava and sweet potato products held at the Indonesia Centre for Agricultural Training (ICAT) of Ketindan and determine the correlation between the participants' areas of origin on improving the performance of agricultural instructors. This research method uses data sources that come from the field obtained by interviewing alumni, fostered farmers, colleagues, and alumni superiors with a survey using a questionnaire. The results of the data were analyzed descriptively and correlated using SPSS Software Version 18 for Windows. The general research results show that the training that has been carried out in 2014, 2015, and 2017 has an effect on increasing the performance of agricultural instructors by $63.20 \%$. This is measured by 3 (three) indicators, namely 1) preparation of agricultural extension by 3.40 or $68.00 \%$; 2) implementation of agricultural extension 2.77 or $55.40 \%$; and 3) evaluation and reporting of 3.29 or $65.80 \%$. The results of the correlation between the participants' regions of origin and the performance of the extension workers showed that the highest performance achievement was 77 and the lowest was 26 . Thus, the extension workers could show good performance in disseminating the application of technological innovations for processing cassava and sweet potato products to farmers or their fostered business actors which affected increasing cassava and sweet potato production and productivity.

\section{Riwayat Artikel \\ Dikirim : 8 Juli, 2021 \\ Disetujui : 15 September, 2021 \\ Diterbitkan : 28 September, 2021 \\ Kata Kunci \\ pelatihan; kinerja; penyuluh \\ pertanian; ubi jalar; ubi kayu}

\section{ABSTRAK}

Penelitian ini bertujuan untuk mengetahui pengaruh pelatihan pengolahan hasil ubi kayu dan ubi jalar yang dilaksanakan di Balai Besar Pelatihan Pertanian (BBPP) Ketindan dan menentukan korelasi antara daerah asal peserta terhadap terhadap peningkatan kinerja penyuluh pertanian. Metode penelitian ini menggunakan sumber data yang berasal dari lapangan yang diperoleh dengan cara wawancara dengan alumni, petani binaan, rekan kerja dan atasan alumni dengan survey menggunakan kuesioner. Data hasil kuesioner dianalisis secara deskriptif dan korelasi menggunakan Software SPSS Versi 18 for Windows. Hasil penelitian secara umum menunjukkan bahwa pelatihan yang telah dilaksanakan pada tahun 2014, 2015 dan 2017 berpengaruh terhadap peningkatan kinerja penyuluh pertanian sebesar $63,20 \%$. Hal tersebut diukur dengan 3 (tiga) indikator yaitu 1) persiapan penyuluhan pertanian sebesar 3,40 atau $68,00 \%$; 2) pelaksanaan penyuluhan pertanian sebesar 2,77 atau $55,40 \%$; dan 3 ) evaluasi dan pelaporan sebesar 3,29 atau $65,80 \%$. Hasil korelasi antara daerah asal peserta terhadap kinerja penyuluh pertanian menunjukkan capaian kinerjanya tertinggi sebesar 77 dan terendah sebesar 26 . Dengan demikian, penyuluh pertanian dapat menunjukkan kinerja yang baik dalam menyebarluaskan penerapan inovasi teknologi pengolahan hasil ubi kayu dan ubi jalar kepada petani atau pelaku usaha binaannya yang berpengaruh pada peningkatan produksi dan produktivitas ubi kayu dan ubi jalar.

Sitasi: Murdani, M., \& Melani, D. (2021). Pengaruh pelatihan pengolahan hasil ubi kayu dan ubi jalar di Balai Besar Pelatihan Pertanian Ketindan terhadap peningkatan kinerja penyuluh pertanian. Agromix, 12(2), 119-128. https://doi.org/10.35891/agx.v12i2.2585

\section{PENDAHULUAN}

Pembangunan pertanian mempunyai kedudukan yang strategis dalam pembangunan sumberdaya manusia pertanian, khususnya pemberdayaan bagi pelaku utama dan pelaku usaha. Konsep pembangunan yang diterapkan selalu menekankan pentingnya kualitas sumber daya manusia pertanian yang merupakan faktor kunci dalam keberhasilan pembangunan pertanian (Zulhendri \& Henmaidi, 2021). Pembangunan pertanian dirasa masih lambat disebabkan oleh banyak hal salah satunya adalah rendahnya kualitas SDM pertanian. Sumber daya manusia atau 
tenaga kerja merupakan faktor penggerak sektor pertanian. Tingkat pendidikan sebagian besar petani masih rendah, sehingga penguasaan akan pengetahuan dan teknologi juga menjadi lemah. Petani tidak berdaya terhadap aksesakses faktor produksi dan pasar (Arifianto dkk., 2018). Dalam rangka mewujudkan pertanian yang tangguh, maka diperlukan upaya pengembangan SDM pertanian yang profesional, kreatif, inovatif, kredibel dan berwawasan global (Hartati, 2011). Peningkatan Sumber Daya Manusia melalui pelatihan adalah investasi yang mahal, maka transfer belajar atau keterampilan dibutuhkan dalam situasi kerja dari peserta pelatihan. Pasca Pelatihan merupakan tahapan yang krusial. Transfer hasil berlatih dalam pelatihan ke dalam situasi kerja memiliki peran yang sangat krusial mengukur keefektifan pelatihan (Salas \& Cannon-Bowers, 2001). Transfer of training dapat ditakrifkan (diberi batasan makna) sebagai: "Aplikasi pengetahuan, keterampilan, dan sikap yang diperoleh peserta dalam pelatihan ke dalam pekerjaan dan pengelolaan hal yang dipelajari itu selanjutnya dalam periode waktu tertentu" The application of knowledge, skills and attitudes learned from training on the job and subsequent maintenance of them over a certain period of time (Kaswan, 2011). Jadi Transfer of Training tidak terbatas hanya memberikan perhatian pada soal efektivitas belajar dalam suatu program pelatihan dan transfer pelatihan terutama dimaksudkan agar terjadi apa yang dinamakan vertical transfer processes dalam pelatihan, yakni: "upward propagation of individual-level training outcomes that emerge as team - and organizational-level outcomes" (Kaswan, 2011).

Kompetensi penyuluh pertanian dalam memberdayakan petani dapat diidentifikasi menjadi tujuh dimensi, yaitu: kemampuan pemahaman potensi wilayah, kemampuan pengelolaan pelatihan, kemampuan pengelolaan pembelajaran, kemampuan pengelolaan komunikasi inovasi, kemampuan pengelolaan kewirausahaan, kemampuan pengelolaan pembaharuan, dan kemampuan pemandu sistem jaringan (Anwas, 2013). Penyuluh merupakan individu yang bertugas mempengaruhi proses pengambilan keputusan sasaran untuk mengadopsi suatu inovasi yang diberikan. UU No. 16/2006 menyebutkan penyuluh adalah perorangan, WNI bisa Pegawai Negeri Sipil, penyuluh swasta dan penyuluh swadaya. Sedangkan Permen PAN No. 2/2008 menegaskan Penyuluh Pertanian adalah Jabatan Fungsional yang memiliki ruang lingkup tugas, tanggung jawab dan wewenang penyuluhan pertanian yang diduduki oleh Pegawai Negeri Sipil yang diberi hak serta kewajiban secara penuh oleh pejabat yang berwenang (Rinofi dkk., 2021). Kompetensi penyuluh terdiri dari kompetensi teknis dan kompetensi manajerial (Bahua, 2018). Kompetensi teknis adalah kemampuan penyuluh pertanian dalam melaksanakan usahatani dengan menerapkan teknologi pertanian, sedangkan kompetensi manajerial adalah kemampuan penyuluh pertanian dalam merencanakan dan mengimplementasikan program penyuluhan yang telah disusun bersama petani (Arifin, 2015).

Tahap-tahap terakhir dalam proses evaluasi adalah pengukuran seberapa efektif pelaksanaan telah dilaksanakan dan seberapa besar efek positifnya pada pelaksanaan kerja di organisasi dan perkembangan para peserta. Selanjutnya, pengukuran bisa dilakukan setelah interval tiga bulan yang disebut dengan evaluasi jangka menengah dan selanjutnya dilakukan dengan interval 12 (dua belas) bulan yang disebut evaluasi jangka panjang (Rae, 2005). Evaluasi untuk mengukur keberhasilan pelaksanaan pelatihan dilakukan tidak hanya mencakup penyelenggaraan tetapi juga pada kemajuan hasil pelatihan. Ukuran kemajuan berlatih dengan membandingkan pre test dan post test melalui perubahan pengetahuan, keterampilan dan sikap sebelum dan sesudah pelatihan. Di sisi yang lain, stakeholder akan lebih melihat work performance setelah Purnawidya kembali melaksanakan tugas pekerjaan sehari-hari dari pada evaluasi kemajuan berlatih selama proses pelatihan berlangsung. Evaluasi untuk melihat perubahan yang terjadi setelah Purnawidya bekerja kembali di tempat asal merupakan fourth stage evaluation atau impact evaluation (Kirkpatrick, 1998). Evaluasi terhadap ukuran keberhasilan seperti yang dipersepsikan oleh stakeholder telah dilakukan secara terbatas, namun belum komprehensif sehingga belum berhasil memberikan gambaran yang cukup signifikan untuk mengukur pengaruh pelatihan Pertanian.

Evaluasi Pendidikan dan Pelatihan merupakan komponen penting dalam sistem pelatihan. Tanpa evaluasi, kita tentu saja tidak mengetahui apakah program pelatihan yang diselenggarakan oleh suatu lembaga pelatihan berhasil atau tidak. Tingkat pencapaian efektivitas dan efisiensi suatu program pelatihan dapat diketahui dari hasil evaluasi pelatihan yang kemudian dapat dijadikan masukan dan bahan pertimbangan dalam pengendalian pelatihan sekaligus untuk bahan penyempurnaan pelatihan di waktu yang akan datang. Mengukur efektivitas program pelatihan membutuhkan waktu dan sumberdaya yang berharga. Banyak program pelatihan yang gagal memberikan manfaat yang diharapkan organisasi. Karena itu, memiliki sistem evaluasi yang terstruktur dengan baik akan membantu organisasi menentukan letak permasalahannya. Salah satu jenis evaluasi yang memiliki manfaat sangat penting dalam sistem pelatihan aparatur adalah evaluasi pengaruh pelatihan (EDP) (Ekawaty, 2014).

Evaluasi Pengaruh Pelatihan merupakan salah satu tahapan dalam siklus manajemen pelatihan, dimana dengan evaluasi pengaruh pelatihan dapat diketahui seberapa besar pelatihan dapat berpengaruh terhadap peningkatan kinerja penyuluh pertanian yang pada akhirnya nanti akan berpengaruh pada peningkatan produksi/produktivitas pertanian yang pada akhirnya dapat meningkatkan pendapatan petani. Indikator kinerja penyuluhan pertanian di wilayah kerjanya diukur berdasarkan tupoksi penyuluh dalam menjalakan tugas kerjanya di wilayah masing-masing, walaupun berbeda wilayah kerjanya akan tetapi secara Nasional indikator ditetapkan secara seragam, agar supaya penilaian kinerja penyuluh mudah dilakukan pemantauan, pengambilan keputusan (Sapar dkk., 2012). Kinerja penyuluh lapangan merupakan kriteria penilaian atas keseluruhan kegiatan kerja yang telah dilakukan untuk kemudian dibandingkan dengan kesesuaian target yang ingin dicapai melalui indikator-indikator yang telah 
ditetapkan. Masalah yang ada di lapangan adalah fakta bahwa sebagian besar penyuluh pertanian memiliki kualitas individu dan kuantitas penyuluhan yang rendah (Hernanda dkk., 2015).

Indikator Penilaian Kinerja meliputi persiapan penyuluhan pertanian yang terdiri dari membuat data potensi wilayah dan agroekosistem; memandu (pengawalan dan pendampingan) penyusunan RDKK; penyusunan programa penyuluhan pertanian desa dan kecamatan; dan membuat Rencana Kerja Tahunan Penyuluh Pertanian (RKTPP) (Anwas, 2013). Indikator kinerja berikutnya adalah pelaksanaan penyuluhan pertanian meliputi melaksanakan desiminasi/penyebaran materi penyuluhan sesuai kebutuhan petani; melaksanakan penerapan metode penyuluhan pertanian di wilayah binaan; melakukan peningkatan kapasitas petani terhadap akses informasi pasar, teknologi, sarana prasarana, dan pembiayaan; menumbuhkan dan mengembangkan kelembagaan petani dari aspek kuantitas dan kualitas; menumbuhkan dan mengembangkan kelembagaan ekonomi petani dari aspek kuantitas dan kualitas; dan meningkatkan produktivitas (dibandingkan produktivitas sebelumnya berlaku untuk semua sub sektor). Evaluasi dan Pelaporan Penyuluhan Pertanian merupakan indikator kinerja terakhir yang terdiri dari melakukan evaluasi pelaksanaan penyuluhan pertanian dan membuat laporan pelaksanaan penyuluhan pertanian (Suwardi, 2009).

Dalam hal tersebut yang menjadikan permasalahan yang dihadapi lembaga pelatihan belum diketahuinya pengaruh pelatihan terhadap outcome pada alumni dalam hal persiapan, pelaksanaan dan mengevaluasi hasil kinerjanya belum diketahui, dengan itu dirumuskan permasalahan pokok yang perlu diangkat tentang seberapa besar pengaruh pelatihan dalam mempersiapkan rencana kerjanya bidang pengolahan hasil ubi jalar dan ubi kayu setelah mengikuti pelatihan; seberapa besar pengaruh pelatihan dalam melaksanakan pekerjaannya dibidang teknologi pengolahan hasil ubi kayu dan ubi jalar setelah mengikuti pelatihan; dan seberapa besar pengaruh pelatihan dalam mengevaluasi hasil pekerjaannya di bidang penerapan teknologi pengolahan hasil ubi kayu dan ubi jalar setelah mengikuti pelatihan. Untuk menjawab permasalahan tersebut perlunya pemantauan efektifitas pelatihan dan dilakukan evaluasi secara individu, grup, atau level organisasi yang mempengaruhi proses pembelajaran dalam pelatihan dan proses transfer setelah pelatihan. Hal tersebut di atas sesuai dengan pendapat (Aguinis \& Kraiger., 2009) dan (Rae, 2005) bahwa pelatihan dan pembelajaran tidak berhenti setelah program berakhir dan setelah rencana kerja yang bagus sudah dibuat. Pelatihan dan pembelajaran terkait dengan masalah perubahan, dan perubahan adalah yang tampak dalam proses di tempat kerja sehingga pelaksanaan tugas, pekerjaan, atau peran, bisa menjadi lebih baik. Untuk memastikan bahwa sudah terjadi perubahan-perubahan adalah tanggung jawab yang harus dimonitor dan di-review. Dari rumusan masalah tersebut diangkat suatu tujuan penelitian ini adalah untuk mengetahui pengaruh pelatihan pengolahan hasil ubi kayu dan ubi jalar terhadap peningkatan kinerja dan kompetensi penyuluh pertanian. Menurut (Roza, 2019), kinerja penyuluh pertanian merupakan capaian hasil kerja penyuluh dalam melaksanakan tugas-tugas yang dibebankan, didasarkan atas kemampuan, pengalaman dan kesungguhan serta penggunaan waktu.

\section{METODE}

Metode pengumpulan data merupakan faktor penting demi tercapainya tujuan yang telah ditetapkan. Hal ini berkaitan dengan bagaimana cara mengumpulkan data, siapa sumbernya, dan alat yang digunakan. Pengumpulan data dan informasi pada kegiatan evaluasi pengaruh pelatihan dilakukan dengan metode pengamatan (observasi) dan wawancara. Penetapan sampel evaluasi pasca pelatihan terdiri dari 43 orang Purnawidya, 17 orang atasan langsung Purnawidya, 18 orang rekan kerja Purnawidya dan 43 orang petani binaan Purnawidya. Penelitian ini dilaksanakan pada tahun 2017-2021 di wilayah kerja Purnawidya masing - masing.

Analisis data dilakukan secara deskriptif, verifikatif dan regresi untuk mengetahui pengaruh pelatihan terhadap peningkatan kinerja penyuluh pertanian, sehingga dapat memberikan jawaban sejauh mana pengaruh pelatihan terhadap kinerja penyuluh pertanian dari persiapan, pelaksanaan dan evaluasi kinerja. Adapun analisis data yang digunakan menggunakan SPSS 18. Sedangkan regresi untuk mengetahui pengaruh fasilitas atasan dan rekan kerja, intensitas bimbingan ke petani dan evaluasi terhadap hasil bimbingan terhadap tingkat penerapan materi. Dengan demikian dapat diketahui pengaruh pelatihan pengolahan hasil ubi jalar dan ubi kayu terhadap kinerja penyuluh pertanian dari persiapan, pelaksanaan dan evaluasi.

\section{HASIL DAN PEMBAHASAN}

\section{Hubungan pelatihan terhadap kinerja Purnawidya}

\section{evaluasi dampak pelatihan}

Hasil wawancara dengan Purnawidya secara keseluruhan menunjukkan pengaruh pelatihan sebesar terhadap peningkatan kinerja penyuluh pertanian sebesar 63,20\%. Berikut adalah data pengaruh pelatihan pada Tahun 2014 , 2015 dan 2017. 
Tabel 1. Evaluasi pengaruh pelatihan terhadap kinerja Purnawidya penyuluh pertanian

\begin{tabular}{|c|c|c|c|c|c|c|c|c|c|c|c|}
\hline \multirow[t]{2}{*}{ Responden } & \multirow{2}{*}{$\begin{array}{c}\text { Asal Responden } \\
\text { (Kabupaten) }\end{array}$} & \multicolumn{2}{|c|}{$\begin{array}{c}\text { Persiapan } \\
\text { Penyuluhan }\end{array}$} & \multicolumn{2}{|c|}{$\begin{array}{l}\text { Pelaksanaan } \\
\text { Penyuluhan }\end{array}$} & \multicolumn{2}{|c|}{$\begin{array}{c}\text { Evaluasi dan } \\
\text { Pelaporan }\end{array}$} & \multirow{2}{*}{$\begin{array}{l}\text { Total } \\
\text { nilai }\end{array}$} & \multirow{2}{*}{$\begin{array}{l}\text { Total } \\
\text { Rerata }\end{array}$} & \multirow[t]{2}{*}{$\%$} & \multirow[t]{2}{*}{ Kriteria } \\
\hline & & Nilai & $\%$ & Nilai & $\%$ & Nilai & $\%$ & & & & \\
\hline 1 & Pacitan & 4,75 & 95,00 & 4,30 & 86,00 & 5,00 & 100,00 & 14,05 & 4,68 & 93,60 & Sangat baik \\
\hline 2 & Ponorogo & 4,75 & 95,00 & 3,90 & 78,00 & 5,00 & 100,00 & 13,65 & 4,65 & 93,00 & Sangat Baik \\
\hline 3 & Trenggalek & 3,81 & 73,75 & 3,20 & 63,50 & 3,08 & 61,65 & 10,07 & 3,36 & 67,10 & Baik \\
\hline 4 & Karanganyar & 4,13 & 82,50 & 3,20 & 64,00 & 3,33 & 66,60 & 10,66 & 3,56 & 71,10 & Baik \\
\hline 5 & Sragen & 2,75 & 55,00 & 2,30 & 46,00 & 3,50 & 70,00 & 8,55 & 2,85 & 57,00 & Cukup Baik \\
\hline 6 & Temanggung & 4,75 & 92,50 & 3,60 & 72,00 & 3,50 & 70,00 & 11,73 & 4,16 & 83,20 & Baik \\
\hline 7 & Wonosobo & 3,50 & 70,00 & 2,40 & 48,00 & 2,17 & 43,30 & 8,07 & 2,69 & 53,80 & Cukup baik \\
\hline 8 & Sumenep & 4,38 & 87,50 & 3,70 & 74,00 & 3,50 & 70,00 & 11,58 & 3,86 & 77,20 & Baik \\
\hline 9 & Sampang & 2,69 & 53,75 & 2,38 & 47,50 & 2,92 & 58,35 & 7,98 & 2,66 & 53,20 & Cukup Baik \\
\hline 10 & Lombok Timur & 4,08 & 81,67 & 2,57 & 51,33 & 2,89 & 57,80 & 9,54 & 3,18 & 63,60 & Baik \\
\hline 11 & Mataram & 1,75 & 35,00 & 1,70 & 34,00 & 2,33 & 46,60 & 5,78 & 1,93 & 38,60 & Kurang baik \\
\hline 12 & Bangli & 2,25 & 45,00 & 1,25 & 25,00 & 1,50 & 30,00 & 5,00 & 1,67 & 33,30 & Kurang baik \\
\hline 13 & Karangasem & 3,75 & 75,00 & 3,20 & 64,00 & 3,67 & 73,30 & 10,62 & 3,54 & 70,70 & Baik \\
\hline 14 & Kulon Progo & 2,75 & 55,00 & 2,25 & 45,00 & 1,84 & 36,70 & 6,84 & 2,28 & 45,50 & Kurang baik \\
\hline 15 & Gunung Kidul & 2,63 & 52,50 & 2,25 & 45,00 & 2,50 & 50,00 & 7,38 & 2,46 & 49,10 & Kurang baik \\
\hline 16 & Probolinggo & 2,38 & 47,50 & 2,40 & 48,00 & 3,84 & 76,70 & 8,61 & 2,87 & 57,40 & Cukup baik \\
\hline 17 & Pasuruan & 3,50 & 70,00 & 2,85 & 57,00 & 4,34 & 86,70 & 10,69 & 3,56 & 71,20 & Baik \\
\hline \multirow[t]{2}{*}{18} & Ende & 1,67 & 33,33 & 1,30 & 26,00 & 3,00 & 60,00 & 5,97 & 1,99 & 39,73 & Kurang Baik \\
\hline & Rata-rata & 3.40 & 68.02 & 2.77 & 55,49 & 3.29 & 65.80 & 9.46 & 3.15 & 63.00 & Baik \\
\hline
\end{tabular}

Sumber : Data primer setelah diolah, 2021

Dengan melihat data pada tabel 1 menunjukkan bahwa pengaruh pelatihan tersebut berpengaruh positif terhadap peningkatan kinerja Purnawidya pelatihan pertanian dalam menjalankan tupoksi, karena pelatihan pengolahan hasil ubi kayu dan ubi jalar merupakan pelatihan yang praktis, aplikatif, menyentuh langsung dengan kebutuhan petani di perdesaan dalam hubungannya memperoleh keuntungan, hal ini didorong dengan ketersediaan bahan baku dan pasar (Suwardi ,2009). Semakin tinggi frekuensi pelatihan yang diikuti seorang penyuluh maka semakin tinggi pula pemahaman dan penguasaan terhadap tugas pokok dan fungsi yang diembannya sehingga akan berpengaruh pada peningkatan kompetensi penyuluh dalam melaksanakan tugasnya (Hanafiah dkk., 2013).

Pengaruh pelatihan menunjukkan setelah pelatihan pekerjaan pada tanaman pangan menurun, sebaliknya pekerjaan pengolahan hasil pertanian, jasa perdagangan dan non-pertanian meningkat, pengaruh perspektif psikososial menunjukkan bahwa kepuasan usaha mempunyai bobot yang paling kuat, diikuti penerimaan, tingkat keuntungan, kemandirian usaha, dan kegiatan membelajarkan orang lain. Kemampuan dan motivasi memberikan pengaruh yang signifikan terhadap kinerja usaha. Sejalan dengan penelitian (Noer dkk., 2020) dimana motivasi berpengaruh signifikan terhadap kinerja penyuluh dengan demikian besarnya motivasi yang diberikan akan meningkatkan kinerja penyuluh. Hal ini membuktikan bahwa sebelum memberikan pelatihan sebaiknya dilakukan analisis kebutuhan dari para penyuluh pertanian (Sinaga \& Ganesha, 2018).

Dari tabel 1 terlihat bahwa pada indikator "persiapan penyuluhan pertanian" sebesar 3,40 atau 68,00\% dengan kategori "baik", indikator "pelaksanaan penyuluhan pertanian" sebesar 2,77 atau 55,40\% dengan kategori "cukup baik" dan indikator "evaluasi dan pelaporan" sebesar 3,29 atau 65,80\% dengan kategori "baik". Dari ketiga indikator tersebut diketahui bahwa pelatihan yang diselenggarakan oleh BBPP Ketindan pada tahun 2014, 2015 dan tahun 2017 telah berpengaruh sebesar 63,20\% terhadap kinerja penyuluh di wilayah kerjanya masing-masing.

\section{Indikator persiapan penyuluhan pertanian}

Pada indikator persiapan penyuluhan pertanian terdiri dari 4 (empat) parameter, yaitu :
a. tersusunnya peta potensi wilayah
b. jumlah RUK/RUB yang telah disusun;
c. peran serta dalam menyusun programa penyuluhan pertanian, dan
d. jumlah inovasi teknologi spesifik lokasi yang tertuang dalam RKPD.

Adapun capaian masing-masing parameter dari indikator persiapan penyuluhan pertanian tersaji pada gambar 1. 


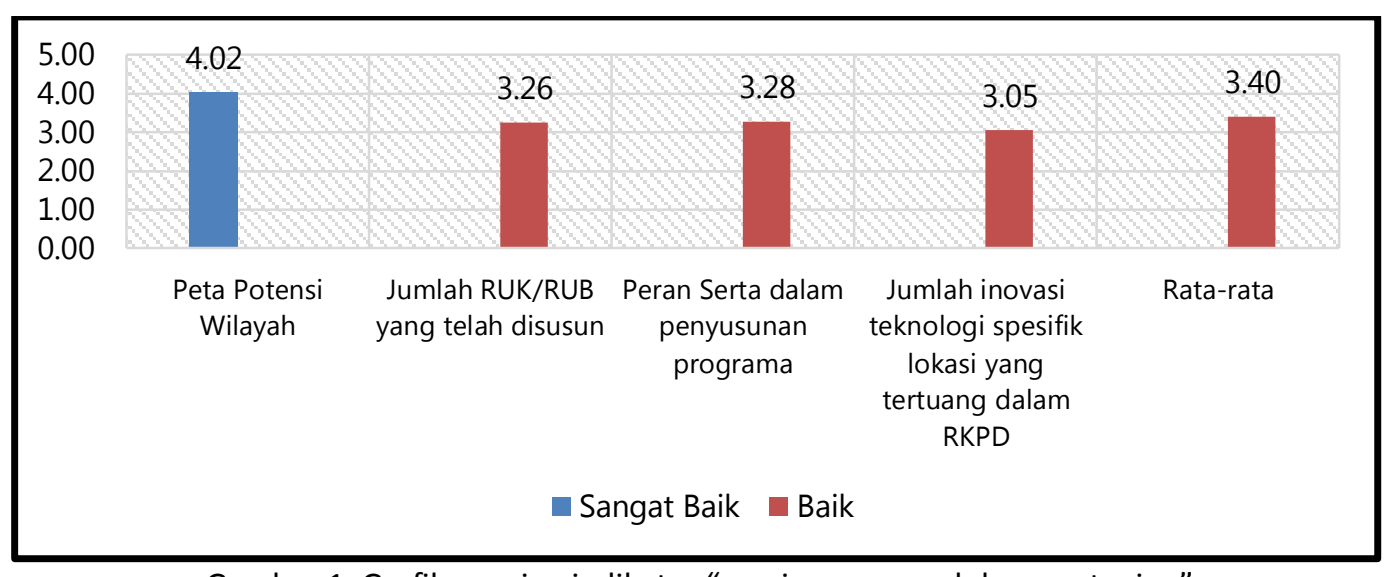

Gambar 1. Grafik capaian indikator "persiapan penyuluhan pertanian"

Sumber : Data primer setelah diolah, 2021

Dari gambar 1 diketahui bahwa pada parameter "peta potensi wilayah" diperoleh rata-rata sebesar 4,02 dengan kategori "sangat baik", artinya bahwa pada peta potensi wilayah penyuluh pertanian telah tergambarkan luas areal tanam (ubi kayu dan ubi jalar), luas areal panen dan rata-rata produktivitas ubi kayu dan ubi jalar. Sedangkan untuk intensitas pertanaman (IP) belum tergambarkan pada peta potensi wilayah yang disusun oleh punyuluh pertanian; Pada parameter "jumlah RUK/RUB yang telah disusun" diperoleh rata-rata sebesar 3,26 dengan kategori "baik", artinya bahwa dari tahun 2014 sampai dengan 2019, penyuluh pertanian telah ikut serta memandu merumuskan atau menyusun RUK/RUB sebanyak 3 RUK/RUB. Pada parameter "peran serta dalam penyusunan programa" diperoleh rata-rata 3,28 dengan kategori "baik", artinya rata-rata dari tahun 2014 sampai dengan 2019 penyuluh telah ikut serta menyusun programa sebanyak 3 kali. Pada parameter "jumlah inovasi teknologi spesifik lokasi yang tertuang dalam RKPD" sebesar 3,05 dengan kategori "baik", artinya RKPD yang disusun oleh penyuluh pertanian rata-rata telah mencakup 3 jenis inovasi teknologi spesifik lokasi yaitu persiapan bahan baku, persiapan alat, proses produksi, pengemasan dan pemasaran.

Dari keempat parameter tersebut, diperoleh rata-rata indikator "persiapan penyuluh pertanian" sebesar 3,40 atau $68,00 \%$ dengan kategori "baik", artinya rata-rata penyuluh pertanian telah melakukan persiapan penyuluhan pertanian dengan baik sebelum melakukan kegiatan penyuluhan kepada petani binaannya masing-masing. Kegiatan persiapan penyuluhan sangat menentukan proses - proses selanjutnya, dengan arti keberhasilan suatu kegiatan penyuluhan tergantung baik tidaknya suatu proses mempersiapkan kegiatan penyuluhan pertanian. Perencanaan adalah proses mendefinisikan tujuan organisasi, membuat strategi untuk mencapai tujuan itu, dan mengembangkan rencana aktivitas kerja organisasi. Perencanaan merupakan proses terpenting dari semua fungsi manajemen karena tanpa perencanaan fungsi-fungsi lain pengorganisasian, pengarahan, dan pengontrolan tak akan dapat berjalan Kementan (2010). Perencanaan dibuat untuk membantu memilih alternatif yang paling baik dan paling efisien. Jadi perencanaan merupakan kumpulan dari pengambilan keputusan. Secara prinsip, perencanaan dilakukan agar setiap kegiatan memiliki tujuan yang jelas dan ada cara yang paling tepat dan efisien untuk mencapai tujuan tersebut. Prinsip utama setiap perencanaan ditujukan untuk pencapaian tujuan. Perencanaan penyuluhan pertanian merupakan proses kegiatan yang mengandung pemilihan usaha-usaha yang akan dilakukan di masa mendatang berdasarkan kondisi saat ini yang meliputi identifikasi masalah-masalah yang dihadapi petani sasaran dan sumberdaya yang tersedia, penentuan materi penyuluhan, metode penyuluhan, personil, waktu dan tempat penyuluhan pertanian, implementasi rencana penyuluhan pertanian, monitor dan mengevaluasi pelaksanaan penyuluhan pertanian J. Ibrahim dkk. ( 2003). Disisi yang lain menurut Harold R. Baker dalam J. Ibrahim dkk. (2003) dijelaskan bahwa elemen-elemen proses perencanaan penyuluhan pertanian meliputi analisis situasi, identifikasi kebutuhan sasaran, inventarisasi sumber daya di tingkat petani, pemilihan metode dan alat bantu penyuluhan, implementasi program serta evaluasi proses dan hasil. Penyuluhan yang berkelanjutan penting sekali dilaksanakan salah satunya dengan memperhatikan penyusunan program penyuluhan pertanian yang dilakukan melalui pendekatan perencanaan bersama (join planning atau participatory planning) yakni kepentingan pemerintah pusat yang berupa kebijakan bersifat top-down dipadukan dengan kebutuhan petani yang bersifat bottom-up (Indraningsih, 2011).

\section{Indikator pelaksanaan penyuluhan}

Pelaksanaan Penyuluhan Pertanian. Pada indikator "pelaksanaan penyuluhan pertanian" terdiri dari 10 (sepuluh) parameter, yaitu :

a. Pelaksanaan desimenasi/ penyebaran materi penyuluhan yang meliputi penerapan inovasi teknologi pengolahan ubi kayu dan ubi jalar;

b. Melaksanakan berbagai metode penyuluhan untuk menyebarluaskan inovasi teknologi peningkatan usaha pengolahan; 
c. Melakukan peningkatan kapasitas petani dalam mengakses informasi pasar dalam mengembangkan usaha tani;

d. Jumlah kelompok tani yang ditingkatkan kapasitas kelembagaannya;

e. Meningkatkan kelas kemampuan kelompok tani dari kelompok kelas pemula ke lanjut;

f. Meningkatkan kelas kemampuan kelompok tani dari kelas lanjut ke madya;

g. Meningkatkan kelas kemampuan kelompok tani dari kelas madya ke utama;

h. Menumbuhkan kelembagaan ekonomi petani (KEP);

i. Mengembangkan kelembagaan ekonomi petani (KEP);

j. Jumlah bimbingan mulai dari persiapan bahan baku, persiapan alat, proses produksi, pengemasan, pemasaran dan permodalan.

Adapun capaian masing-masing parameter dari indikator pelaksanaan penyuluhan tersaji pada gambar 2.

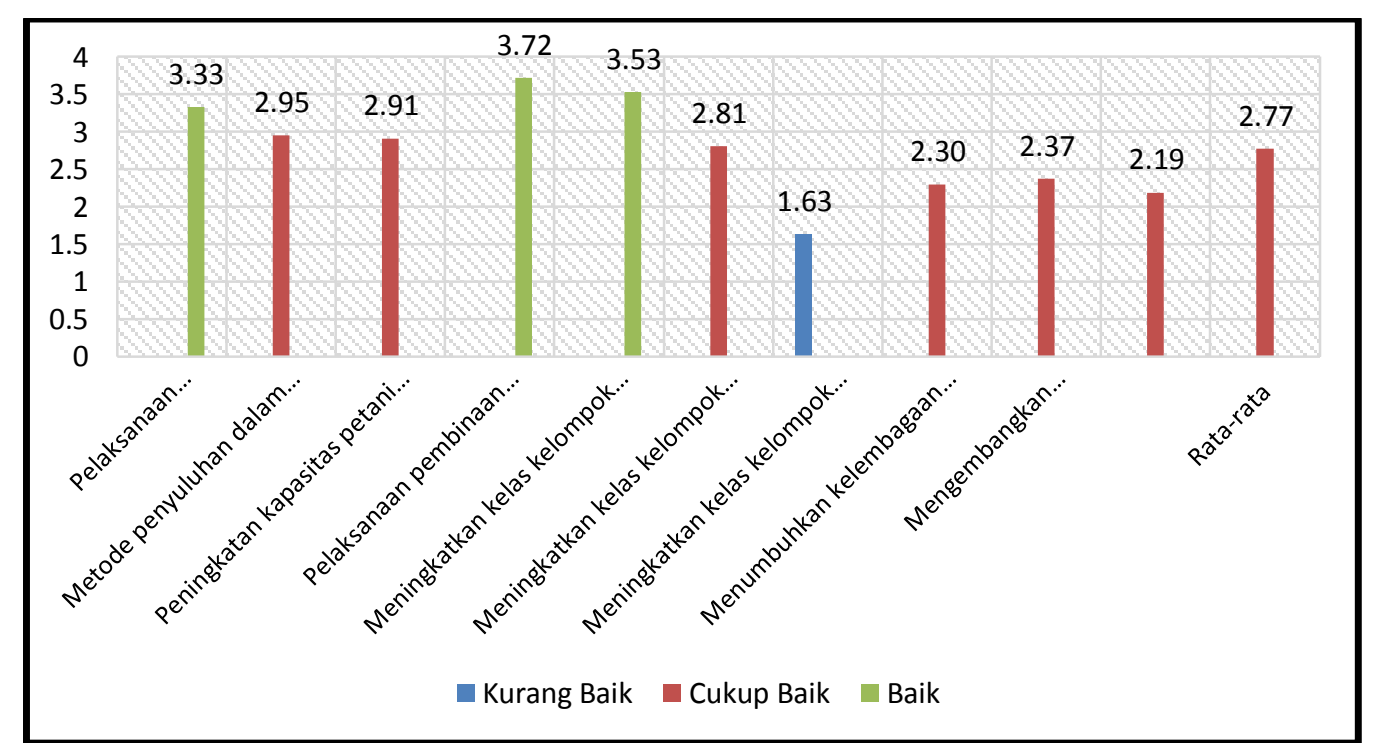

Gambar 2. Grafik capaian indikator "pelaksanaan penyuluhan pertanian"

Sumber : Data primer setelah diolah, 2021

Dari gambar 2 diketahui bahwa pada parameter "pelaksanaan desimenasi/penyebaran materi penyuluhan yang meliputi penerapan inovasi teknologi pengolahan ubi kayu dan ubi jalar" diperoleh rata-rata sebesar 3,33, dengan kategori "baik", artinya rata-rata penyuluh pertanian telah melakukan desiminasi/penyebaran materi penyuluhan sebanyak 3 jenis inovasi teknologi spesifik lokasi. Pada parameter "melaksanakan berbagai metode penyuluhan untuk menyebarluaskan inovasi teknologi peningkatan usaha pengolahan" diperoleh rata-rata sebesar 2,95, dengan kategori "cukup baik", artinya rata-rata dalam melakukan penyuluhan penyuluh telah menggunakan 3 metode penyuluhan, yaitu demonstrasi, FFD (farmers field days) dan kunjungan/tatap muka). Pada parameter "melakukan peningkatan kapasitas petani dalam mengakses informasi pasar dalam mengembangkan usaha tani" diperoleh rata-rata sebesar 2,91, dengan kategori "cukup baik", artinya penyuluh telah melakukan 3 jenis metode untuk meningkatkan kapasitas petani dalam mengakses informasi pasar dalam mengembangkan usahatani, yaitu dengan cara memberikan informasi dan menunjukkan sumber informasi; membangun jejaring kerja antar petani; dan membangun kemitraan

Pada parameter "jumlah kelompok tani yang ditingkatkan kapasitas kelembagaannya" diperoleh rata-rata 3,72, dengan kategori "baik", artinya rata-rata penyuluh pertanian telah mampu melakukan pembinaan peningkatan kapasitas kelembagaan kelompok tani sebanyak 3 kelompok tani. Pada parameter "meningkatkan kelas kemampuan kelompok tani dari kelompok kelas pemula ke lanjut" diperoleh rata-rata sebesar 3,53, dengan kategori "baik", artinya rata-rata penyuluh pertanian telah meningkatkan kelas kemampuan kelompok tani dari kelompok kelas pemula ke lanjut sebanyak 2 kelompok tani, Pada parameter "meningkatkan kelas kemampuan kelompok tani dari kelas lanjut ke madya" diperoleh rata-rata sebesar 2,81, dengan kategori "cukup baik", artinya rata-rata penyuluh pertanian telah meningkatkan kelas kemampuan kelompok tani dari kelompok kelas lanjut ke utama sebanyak 1 kelompok tani; Pada parameter " meningkatkan kelas kemampuan kelompok tani dari kelas madya ke utama" diperoleh rata-rata sebesar 1,63, dengan kategori "kurang baik", artinya rata-rata penyuluh pertanian mampu meningkatkan kelas kelompok tani dari kelas kelompok madya ke kelas kelompok utama, baru pada tahap meningkatkan nilai/skor kelompok pada kelas kelompok yang sama; Pada parameter "menumbuhkan kelembagaan ekonomi petani (KEP)" diperoleh rata-rata sebesar 2,30, dengan kategori "cukup baik", artinya rata-rata penyuluh telah dapat menumbuhkan kelembagaan ekonomi petani (KEP) sebanyak 1 KEP, yaitu simpan pinjam; Pada parameter "mengembangkan kelembagaan ekonomi petani (KEP)", diperoleh rata-rata 2,37, dengan kategori "cukup baik", artinya rata-rata penyuluh pertanian telah mengembangkan kelembagaan ekonomi petani (KEP) sebanyak 1 KEP, yaitu simpan pinjam; Pada parameter 
"jumlah bimbingan mulai dari persiapan bahan baku, persiapan alat, proses produksi, pengemasan, pemasaran dan permodalan" diperoleh rata-rata sebesar 2,19, dengan kategori "cukup baik", artinya rata-rata penyuluh pertanian baru melakukan bimbingan mulai dari persiapan bahan baku, persiapan alat, proses produksi, pengemasan, pemasaran dan permodalan sebanyak 2-3 kali, hal ini dikarenakan keterbatasan alat pengolahan dan ketersediaan bahan baku yang bergantung musim;

Dari 12 parameter tersebut diperoleh rata-rata pada indikator "pelaksanaan penyuluhan pertanian" sebesar 2,77 atau 55,40\% dengan kategori "cukup baik". Hal ini berarti kinerja penyuluh dalam melaksanakan penyuluhan pertanian perlu ditingkatkan lagi , terutama pada parameter meningkatkan kelas kemampuan kelompok tani dari kelas madya ke utama, menumbuhkan dan mengembangkan kelembagaan ekonomi petani (KEP), serta meningkatkan kegiatan bimbingan mulai dari persiapan bahan baku, persiapan alat, proses produksi, pengemasan, pemasaran dan permodalan.

Melihat penyataan di atas dalam pelaksanaan penyuluhan banyak faktor yang dihadapi penyuluh pertanian baik interen (dukungan lembaga organisasi penyuluhan dalam hal ini dinas Pertanian setempat), maupun external (lembaga permodalan, pasar, SDM dan SDA, lembaga lainnya yang terkait), dengan itu seorang penyuluh harus mempunyai multidisipliner (Slamet, 2003).

Dari data di atas kinerja penyuluh pertanian menunjukkan rata-rata cukup baik hal ini dipengaruhi penggunaan metoda penyuluhan/komunikasi dari masing-masing penyuluh berbeda dan cara penyampaian materi juga berbeda akan sangat mempengaruhi daya terima petani. Hal demikian, sesuai dengan pendapat (Sudiyono dkk., 2003), penggunaan media dalam proses pengajaran sangat dianjurkan untuk mempertinggi kualitas pengajaran. Selain itu penggunaan ICT (Information and communication technology) menurut Idrisa et al (2013:70) sangat penting pada bidang penyuluhan pertanian. Hasil penelitian (Indraningsih, 2011) bahwa ICT menjadi metode yang paling efektif untuk pelatihan, bahwa ICT menjadi metode yang paling efektif untuk pelatihan, menginformasikan dan menyebarluaskan teknologi petani di daerah pedesaan, penggunaan teknologi bagi penyuluh memudahkan penyuluh untuk menjawab pertanyaan petani terkait masalah pertanian, menginformasikan harga pasar, prakiraan cuaca dan lain-lain. menginformasikan dan menyebarluaskan teknologi petani di daerah pedesaan, penggunaan teknologi bagi penyuluh memudahkan penyuluh untuk menjawab pertanyaan petani terkait masalah pertanian, menginformasikan harga pasar, prakiraan cuaca dan lain-lain.

\section{Indikator evaluasi dan pelaporan}

Pada indikator "evaluasi dan pelaporan" terdiri dari 3 parameter, yaitu : a). melakukan evaluasi pelaksanaan penyuluhan pertanian; b). menyusun laporan pelaksanaan penyuluhan pertanian; dan c). jumlah kelompok tani binaan yang sudah menerapkan paket lengkap inovasi teknologi pengolahan hasil. Adapun capaian masing-masing parameter dari indikator evaluasi dan pelaporan tersaji pada gambar 3.

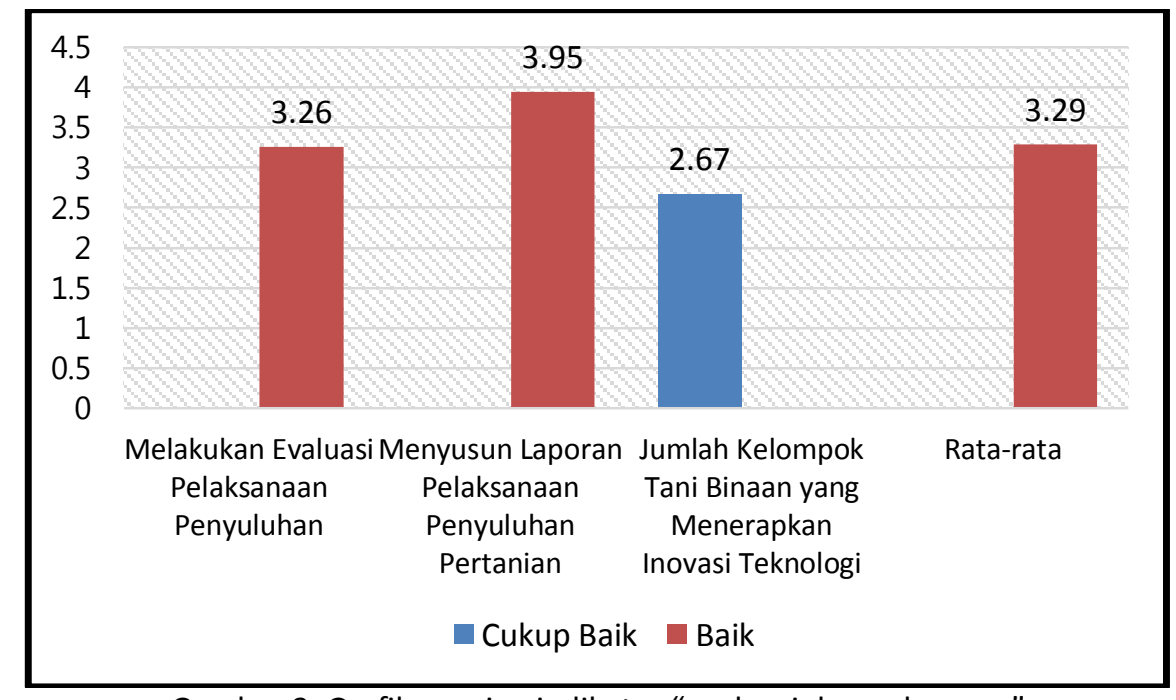

Gambar 3. Grafik capaian indikator "evalausi dan pelaporan" Sumber : Data primer setelah diolah, 2021

Dari gambar 3 diketahui bahwa pada parameter "melakukan evaluasi pelaksanaan penyuluhan" diperoleh ratarata sebesar 3,26, dengan kategori "baik", artinya rata-rata penyuluh pertanian telah melakukan evaluasi pelaksanaan penyuluhan pertanian sebanyak 2 kali per tahun; pada parameter "menyusun laporan pelaksanaan penyuluhan pertanian" diperoleh rata-rata 3,95, dengan kategori "baik", artinya rata-rata penyuluh pertanian telah menyusun laporan pelaksanaan penyuluhan pertanian sebanyak 3 jenis pelaporan, yaitu laporan setiap triwulan, setiap semester dan dan setiap tahun. Walaupun demikian ada beberapa kabupaten/kota yang telah menerapkan laporan harian, seperti Kabupaten Pacitan, Kabupaten Ponorogo, Kabupaten Sumenep, dan yang lainnya; pada parameter "jumlah 
kelompok tani binaan yang telah menerapkan paket lengkap inovasi teknologi pengolahan hasil" diperoleh rata-rata sebesar 2,67, dengan kategori "cukup baik", artinya rata-rata 30\% sampai dengan 40\% kelompok tani dari jumlah kelompok tani binaan yang telah menerapkan paket lengkap inovasi teknologi pengolahan hasil;

Dari ketiga parameter tersebut diperoleh rata-rata indikator "evaluasi dan pelaporan" sebesar 3,29 atau 65,80\% dengan kategori "baik", hal ini berarti pada indikator "evaluasi dan pelaporan" penyuluh pertanian masih perlu ditingkatkan.

Hasil analisis responden atasan langsung dan rekan kerja Purnawidya diharapkan setelah 2 (dua) sampai 5 (lima) tahun Purnawidya mengikuti pelatihan, Purnawidya dapat menunjukkan peningkatan kinerja dalam menyebarluaskan penerapan inovasi teknologi pengolahan hasil ubi kayu dan ubi jalar kepada rekan kerja maupun petani binaannya yang diharapkan dapat berpengaruh pada peningkatan produksi dan produktivitas, yang akhirnya dapat meningkatkan pendapatan petani/pelaku usaha. Adapun hasil diskusi tersebut adalah sebagai berikut:

a. Menurut atasan langsung dan rekan kerja, Purnawidya telah menerapkan RTL yang disusun oleh Purnawidya pada saat mengikuti pelatihan, yaitu dengan melaporkan RTL yang disusun kepada atasan langsung, telah melakukan sosialisasi kepada rekan kerja dan telah menyampaikan materi-materi yang diperoleh selama pelatihan kepada petani binaannya;

b. Pengaruh pelatihan terhadap perubahan perilaku petani dalam menerapkan paket teknologi pengolahan hasil ubi kayu dan ubi jalar sangat baik, yang antara lain ditunjukkan dengan beralihnya penjualan hasil panen langsung/mentah menjadi bentuk olahan pangan, adanya perubahan perilaku dalam melakukan proses pengolahan dengan menjaga kebersihan alat dan bahan yang sesuai SOP, kemasan dan pelabelan produk olahan semakin baik dan menarik, dan lain sebagainya;

c. Pengaruh pelatihan terhadap peningkatan volume produksi, adalah rata-rata ada peningkatan dari tahun ke tahun walaupun sedikit. Hal ini dapat diketahui dengan semakin banyaknya jenis produk olahan dengan bahan dasar ubi kayu dan ubi jalar;

d. Pengaruh pelatihan terhadap peningkatan pendapatan, adalah rata-rata ada peningkatan pendapatan ditingkat rumah tangga petani karena adanya tambahan pemasukan dari kegiatan pengolahan hasil;

e. Pengaruh pelatihan terhadap peningkatan jejaring pemasaran, adalah semakin memperluas dan menambah wilayah pemasaran, dimana sebelumnya hanya di tingkat desa/kecamatan, pemasarannya semakin luas di tingkat kabupaten dan sampai luar kabupaten;

f. Menurut atasan langsung rata-rata kinerja Purnawidya semakin baik setelah mengikuti pelatihan;

g. Faktor-faktor yang mendukung terwujudnya pengaruh pelatihan, adalah :

- Ketersediaan sumber daya manusia yang memadai;

- Ketersediaan sarana prasarana yang berkelanjutan;

- Kebijakan organisasi, guna mendukung program diversifikasi pangan dan program pengembangan bahan pangan lokal, pemerintah daerah memberikan bantuan peralatan dan fasilitas pelatihan bagi pelaku usaha serta membantu mengenalkan produk olahan pangan melalui kegiatan pameran, bazzar, lomba cipta menu dan lain-lain;

h. Faktor-faktor yang menghambat terwujudnya pengaruh pelatihan :

- Ketersediaan bahan baku ubi kayu dan ubi jalar yang masih tergantung musim;

- Peralatan pengolahan hasil yang masih manual dan sederhana;

- Masih kurangnya sentuhan teknologi dan inovasi baru terkait dengan produk olahan agar lebih menarik.

Diskusi juga dilakukan bersama petani/pelaku usaha binaannya untuk mengetahui sejauh mana penerapan hasil belajar Purnawidya di wilayah kerja masing-masing. Diharapkan setelah 2 sampai 5 tahun Purnawidya mengikuti pelatihan, inovasi teknologi pengolahan hasil ubi kayu dan ubi jalar baik yang disampaikan kepada petani/pelaku usaha binaannya yang diharapkan dapat berpengaruh pada peningkatan produksi dan produktivitas, yang akhirnya dapat meningkatkan pendapatan petani/pelaku usaha. Adapun hasil diskusi tersebut adalah sebagai berikut :

a. Rata-rata Purnawidya terlibat dalam menyusun rencana usaha pengolahan hasil ubi kayu dan ubi jalar sebanyak 5 kali. Hal ini menunjukkan bahwa Purnawidya berperan aktif dalam kegiatan pengolahan hasil di wilayah binaannya;

b. Inovasi teknologi yang dihasilkan oleh Purnawidya dalam pengolahan ubi kayu dan ubi jalar rata-rata 3 macam. Adapun bentuk inovasi teknologi pengolahan hasil ubi kayu dan ubi jalar antara lain : tepung mocaf, stik, brownies, tiwul instan, keripik, rengginang, dodol dan aneka kue;

c. Pengaruh pelatihan terhadap peningkatan kelas kelompok menurut petani/pelaku usaha binaan Purnawidya adalah sebanyak 16 kelompok. Meskipun tidak seluruhnya meningkat, namun terjadi peningkatan pengetahuan dan keterampilan di bidang pengolahan hasil;

d. Petani binaan/pelaku usaha telah melakukan jejaring kerja sama dan kemitraan, rata-rata jumlah mitra kerja yang bekerja sama dengan petani binaan/ pelaku usaha sebanyak 4 kemitraan. Adapun mitra tersebut berada di lingkup desa sampai luar kabupaten, sedangkan bentuk kemitraan berupa penyediaan bahan baku dan pemasaran produk olahan; 
e. Kesulitan dan permasalahan yang dihadapi petani/pelaku usaha antara lain :

- Proses produksi sebagian besar masih manual, belum menggunakan mesin

- Ketersediaan bahan baku terbatas, terutama saat diluar musim

- $\quad$ Pemasaran produk olahan yang kurang mendukung

\section{Analisis korelasi}

Hasil korelasi antara kabupaten asal Purnawidya dengan capaian kinerja dari hasil korelasi antara kabupaten asal Purnawidya dengan kinerja Purnawidya diperoleh bahwa Purnawidya yang capaian kinerjanya tertinggi dengan nilai 77 berasal dari Kabupaten Pacitan, sedangkan peserta yang capaian kinerjanya terendah dengan nilai 26 berasal dari Kabupaten Bangli. Adapun hasil korelasi antara kabupaten asal Purnawidya dengan capaian kinerja Purnawidya dapat digambarkan seperti pada gambar 4.

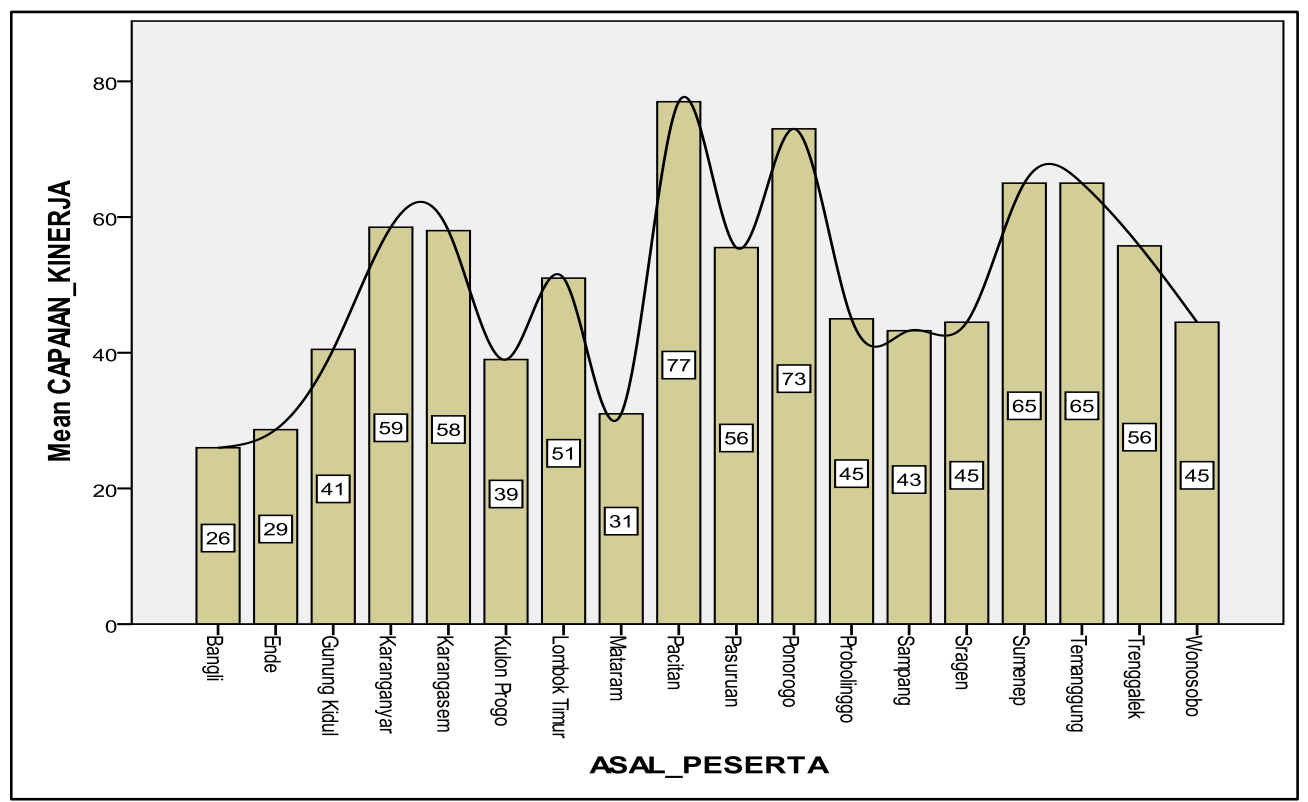

Gambar 4. Grafik hasil korelasi antara kabupaten asal Purnawidya dengan capaian kinerja Purnawidya

\section{KESIMPULAN}

Dari hasil analisis dan pembahasan dapat disimpulkan bahwa pengaruh pelatihan dapat disimpulkan bahwa secara keseluruhan pelatihan yang telah dilaksanakan BBPP Ketindan pada tahun 2014, 2015 dan 2017 berpengaruh terhadap peningkatan kinerja penyuluh pertanian sebesar 63,20\%. Capaian kinerja Purnawidya diukur dari 3 (tiga) indikator, yaitu : a) "persiapan penyuluhan pertanian" sebesar 3,40 atau 68,00\%; b) "pelaksanaan penyuluhan pertanian" sebesar 2,77 atau 55,40\%; dan c) "evaluasi dan pelaporan" sebesar 3,29 atau 65,80\%. Hasil korelasi antara daerah asal Purnawidya dengan kinerja= diperoleh hasil bahwa Purnawidya yang capaian kinerjanya tertinggi dengan nilai 77 berasal dari Kabupaten Pacitan, sedangkan peserta yang capaian kinerjanya terendah dengan nilai 26 berasal dari Kabupaten Bangli. Dari hasil evaluasi pelaksanaan kegiatan evaluasi pengaruh pelatihan dapat disarankan bahwa materi pelatihan pengolahan hasil ubi kayu dan ubi jalar perlu penambahan materi alat dan mesin pengolahan hasil pertanian yang lebih sederhana sehingga mudah diaplikasikan di masyarakat desa; perlu penambahan materi kemitraan dan jejaring pemasaran dalam kegiatan pelatihan.

\section{DAFTAR PUSTAKA}

Aguinis, H., \& Kraiger., K. (2009). Benefits of training and development for individuals and teams, organizations, and society. Annual Review of Psychology, 60, 451-474. https://doi.org/10.1146/annurev.psych.60.110707.163505

Anwas, O. M. (2013). Pengaruh pendidikan formal, pelatihan, dan intensitas pertemuan terhadap kompetensi penyuluh pertanian. Jurnal Pendidikan dan Kebudayaan, 19(1), $50-62$.

Arifianto, S., Satmoko, S., \& Setiyawan, B. M. (2018). Pengaruh karakteristik penyuluh, kondisi kerja, motivasi terhadap kinerja penyuluh pertanian dan pada perilaku petani padi di Kabupaten Rembang. Agrisocionomics: Jurnal Sosial Ekonomi Pertanian, 1(2), 166-180. https://doi.org/10.14710/agrisocionomics.v1i2.1888

Arifin, M. (2015). Analisis tingkat kepuasan petani terhadap kinerja pelayanan penyuluh pertanian (studi kasus di BP3K Kalibawang, Kab. Kulon Progo, D.I. Yogyakarta). Agrica Ekstensia, 9(1), 40-49.

Bahua, M. I. (2018). Peran kompetensi penyuluh pertanian pada keterampilan petani bawang merah. Agriekonomika, 7(2), 112-119. https://doi.org/10.21107/agriekonomika.v7i2.4489 
Ekawaty, A. (2014). Faktor - faktor yang mempengaruhi kinerja petugas penyuluh lapangan pertanian pada Badan Pelaksana Penyuluhan Pertanian, Perikanan,Kehutanan dan Ketahanan Pangan (BP4KKP) di Kecamatan Sepauk Kabupaten Sintang [Tesis]. Universitas Terbuka.

Hanafiah, M. A., Rasyid, W., \& Purwoko, A. (2013). Hubungan karakteristik, motivasi dan kompetensi terhadap produktivitas kerja penyuluh pertanian di Kota Bengkulu. Jurnal AGRISEP, 12(1), 69-84. https://doi.org/10.31186/jagrisep.12.1.69-84

Hartati, P. (2011). Analisis kinerja penyuluh pertanian di Kabupaten Bantaeng Sulawesi Selatan. Jurnal Agrisistem, 7(2), 95-97.

Hernanda, T. A., Fatchiya, A., \& Sarma, M. (2015). Tingkat kinerja penyuluh pertanian di Kabupaten Ogan Komering Ulu (OKU) Selatan. Jurnal Penyuluhan, 11(1), 79-90. https://doi.org/10.25015/penyuluhan.v11i1.9937

Indraningsih, K. S. (2011). Pengaruh penyuluh terhadap keputusan petani dalam adopsi inovasi teknologi usahatani terpadu. Jurnal Agro Ekonomi, 29(1), 1-24. http://dx.doi.org/10.21082/jae.v29n1.2011.1-24

Kaswan. (2011). Pelatihan dan pengembangan untuk meningkatkan kinerja SDM. Alfabeta.

Kirkpatrick, D. L. (1998). Evaluating training programs: the four levels. Berrett-Koehler Publisher, Inc.

Noer, N. V., Suddin, A., \& Sriwidodo, U. (2020). Pengaruh pelatihan, kompensasi, dan motivasi terhadap kinerja penyuluh. Jurnal Manajemen Sumber Daya Manusia, 14(1), 152-161.

Rae, L. (2005). Using training aids in training and development: a practical guide for trainers and presenters. PT Bhuana Ilmu Populer.

Rinofi, Manjas, E., \& Iswara, W. (2021). Pengaruh pelatihan manajemen penyuluhan terhadap kinerja Tenaga Harian Lepas Tenaga Bantu Penyuluh Pertanian (THL-TBPP) di Sumatera Barat. Jurnal Niara, 14(1), $161-168$. https://doi.org/10.31849/niara.v14i1.5979

Roza, E., Rosnita, R., \& Restuhadi, F. (2018). Faktor-Faktor yang mempengaruhi kinerja penyuluh pertanian dan dampaknya terhadap produksi padi petani di Kabupaten Siak. PEKBIS (Jurnal Pendidikan Ekonomi Dan Bisnis), 10(1), 1-11.

Salas, E., \& Cannon-Bowers, J. A. (2001). The science of training: A decade of progress. Annual review of psychology, 52(1), 471-499. https://doi.org/10.1146/annurev.psych.52.1.471

Sapar, S., Jahi, A., Saleh, A., \& Purnaba, I. P. (2012). Kinerja penyuluh pertanian dan dampaknya pada kompetensi petani kakao di empat wilayah Sulawesi Selatan. Jurnal Penyuluhan, 8(1), 29-41. https://doi.org/10.25015/penyuluhan.v8i1.9892

Sinaga, H. R. (2018). Pengaruh pelatihan dan pendidikan terhadap kinerja penyuluh pertanian pada BKP5K Kabupaten Bogor. Jurnal E-Bis (Ekonomi-Bisnis), 2(2), 64-70. https://doi.org/10.37339/e-bis.v2i2.85

Slamet, M. (2003). Membentuk pola perilaku manusia pembangunan (Ida Yustina \& A. Sudradjat (eds.)). Institut Pertanian Bogor.

Sudiyono, A., Harpowo, \& Ibrahim, J. T. (2003). Komunikasi dan penyuluhan pertanian. Bayumedia Publishing dan UMM Press.

Suwardi. (2009). Model evaluasi kinerja tamatan pelatihan. Balai Pelatihan Pertanian DIY.

Zulhendri, A., \& Henmaidi. (2021). Pengaruh pendidikan dan pelatihan terhadap kompetensi penyuluh pertanian di kabupaten pasaman. Jurnal Niara, 14(2), 35-43. https://doi.org/10.31849/niara.v14i2.5871 